\title{
Interaction of cancer cells with magnetic nanoparticles modified by methacrylamido-folic acid
}

\author{
This article was published in the following Dove Press journal: \\ International Journal of Nanomedicine \\ 25 February 201I \\ Number of times this article has been viewed
}

Nagehan Saltan'

H Mehtap Kutlu²

Deniz Hür ${ }^{3,4}$

Arzu İșcan ${ }^{4}$

Rıdvan Say ${ }^{3}$

'Department of Pharmaceutical

Botanics, Faculty of Pharmacy,

${ }^{2}$ Department of Biology,

${ }^{3}$ Department of Chemistry,

Faculty of Science, ${ }^{4}$ Plant, Drug

and Scientific Research Center

Anadolu University, Eskișehir, Turkey
Correspondence: Hatice Mehtap Kutlu Anadolu University, Faculty of Science, Department of Biology, 26470 Eskișehir, Turkey

Tel +902223350580 4721

$\mathrm{Fax}+902223204910$

Email hmkutlu@anadolu.edu.tr
Background: Magnetic nanoparticles show great promise for use as tools in a wide variety of biomedical applications. The purpose of this study was to investigate the potential effects of methacrylamido-folic acid (Ma-Fol)-modified magnetic nanoparticles on 5RP7 (H-ras-transformed rat embryonic fibroblasts) and NIH/3T3 (normal mouse embryonic fibroblasts).

Methods: The cytotoxicity and viability of 5RP7 and NIH/3T3 cells were detected. The percentage of cells undergoing apoptosis was analyzed by flow cytometry using Annexin V-fluorescein isothiocyanate staining. Nanoparticle internalization into 5RP7 and NIH/3T3 cells was visualized by transmission electron microscopy.

Conclusion: In this study, folic acid coupled to the surface of iron oxide for selective binding to cancer cells and immobilized the surfaces of magnetic nanoparticles. This complex improves cell internalization and targeting of cancer cells. We detected increased apoptosis using flow cytometry and transmission electron microscopy.

Results: Folic acid modification of magnetic nanoparticles could be used to facilitate uptake to specific cancer cells for cancer therapy and diagnosis. Our results showed that the uptake of folic-acid modified nanoparticles by 5RP7 cancer cells was also much higher than that of 3T3 cells. This modification can be used for successful targeting of cancer cells expressing the folate receptor.

Keywords: folic acid, apoptosis, nanoparticles, transmission electron microscopy

\section{Introduction}

Cancer affects millions of people in all age groups. Many conventional cancer chemotherapies are ineffective because of an inability to reach the tumor site in effective concentrations. ${ }^{1}$ There is little doubt that nanoparticles offer new opportunities in many fields. ${ }^{2}$ Nanotechnology is expected to revolutionize medicine. Nanostructures can play a major role in medicine, especially in cancer diagnosis and therapy. ${ }^{3}$

Magnetic nanoparticles have been investigated for various biomedical applications, eg, $\mathrm{Fe}_{3} \mathrm{O}_{4}$ nanoparticles, and prospected in diagnostic research for magnetic resonance imaging and application of nanotechnologies in medicine. ${ }^{4}$ Magnetic nanoparticles could enhance therapeutic effects and reduce side effects of drugs when used in combination with conventional cancer treatment. ${ }^{5}$ The combination of $\mathrm{Fe}_{3} \mathrm{O}_{4}$ magnetic nanoparticles with different chemotherapeutics may provide new strategies in the treatment of specific cancer cells. ${ }^{6}$

Moreover, $\mathrm{Fe}_{3} \mathrm{O}_{4}$ nanoparticles are the only magnetic nanomaterials approved for clinical use by the US Food and Drug Administration, and the preparation method 
is relatively simple. ${ }^{7}$ We aimed to determine whether the anticancer effects of methacrylamido-folic acid (Ma-Fol) would have improved anticancer activity if incorporated into magnetic nanoparticles. We demonstrated that magnetic $\mathrm{Fe}_{3} \mathrm{O}_{4}$ nanoparticles coupled with folic acid can inhibit tumor proliferation and induce apoptosis of cancer cells in a dose- and time-dependent manner.

Folic acid is a water-soluble vitamin. It has been used for targeting drugs to cancer cells. The folate receptor is significantly overexpressed on the surface of human cancer cells. ${ }^{8,9}$ Folate receptor-mediated drug delivery is based on conjugation with folic acid, which is internalized by folate receptor-mediated endocytosis. Folic acid has been immobilized on superparamagnetic particles, ${ }^{10}$ polymer nanoparticles, ${ }^{11}$ and incorporated into dendrimer-based therapeutic nanodevices ${ }^{12}$ for selective targeting of tumor cells. Folate receptors exhibit limited expression on healthy cells, but are often present in large numbers on cancer cells. ${ }^{13}$ Folic acid receptors are overexpressed by epithelial cancers in the ovary, mammary gland, colon, lung, prostate, nose, throat, and brain, ${ }^{14}$ so represent an important target for tumor-specific delivery of anticancer drugs.

Cell death can be categorized as apoptosis and as necrosis. Apoptosis, or programmed cell death, is an active process characterized by cytoplasmic shrinkage, chromatin condensation, nuclear fragmentation, and activation of caspases. ${ }^{13}$ In addition, phosphatidylserine is exposed on the external surface of the cell in the early phase of apoptosis, and this exposure precedes membrane damage and DNA fragmentation. ${ }^{15}$ On the other hand, necrosis is passive, and is characterized by cell swelling, rupture of the plasma membrane, and cell lysis, with leakage of cytoplasmic components, such as lactate dehydrogenase. ${ }^{13}$ In the present study, folic acid was coupled on the surface of $\mathrm{Fe}_{3} \mathrm{O}_{4}$ for selective binding to cancer cells and immobilized on the surfaces of magnetic nanoparticles, to disperse particles and improve their cell internalization and target cancer cells, respectively. Further, the apoptotic effects of Ma-Fol-modified $\mathrm{Fe}_{3} \mathrm{O}_{4}$ nanoparticles were determined in a 5RP7 (H-ras-transformed rat embryonic fibroblasts) and in a NIH/3T3 control cell line (normal mouse embryonic fibroblasts) by flow cytometry and transmission electron microscopy (TEM).

Nanoparticles are generally internalized into cells via fluid-phase endocytosis, ${ }^{16,17}$ receptor-mediated endocytosis, or phagocytosis. One strategy to realize efficient and specific cellular uptake of nanoparticles is to modify the nanoparticle surface with a ligand that is efficiently taken up by target cells via receptor-mediated endocytosis. ${ }^{18}$
The objective of this research was to assess the potential effects of $\mathrm{Fe}_{3} \mathrm{O}_{4}$ magnetic nanoparticles modified with Ma-Fol on 5RP7 cancer cells and NIH/3T3 cells.

\section{Materials and methods Synthesis and characterization of magnetic nanoparticles with $\mathrm{Ma}-\mathrm{Fol}$}

Folic acid (1 equivalent) was dissolved in $50 \mathrm{~mL}$ of water. $\mathrm{pH}$ was set to $9-10$ by addition of $1 \mathrm{M} \mathrm{NaOH}$ solution to obtain anionic folate in solution. A solution of methacryloyl benzotriazole ${ }^{19,20}$ in dioxane $(15 \mathrm{~mL})$ was added to the folate solution. This mixture was stirred for 30 minutes at room temperature. Completion of the reaction was monitored by thin layer chromatography, which showed free $1 H$-benzotriazole spot. Dioxane was evaporated under vacuum. Reaction mixture was extracted with ethyl acetate $(3 \times 20 \mathrm{~mL})$ to remove $1 H$-benzotriazole. Water layers were acidified with $0.1 \mathrm{M} \mathrm{HCl}$ solution to adjust to $\mathrm{pH}$ 5-6. Water was evaporated under vacuum to get Ma-Fol as yellow microcrystals in an $85 \%$ yield.

${ }^{1} \mathrm{H}$ nuclear magnetic resonance (NMR, $500 \mathrm{mHz}$, DMSO-d6) $\delta$ was as follows: $8.56(\mathrm{~s}, 1 \mathrm{H}), 7.59$ $\left(\mathrm{d},{ }^{3} \mathrm{~J}_{\mathrm{HH}}=8.80 \mathrm{~Hz}, 1 \mathrm{H}\right), 6.65\left(\mathrm{~d},{ }^{3} \mathrm{~J}_{\mathrm{HH}}=8.80 \mathrm{~Hz}, 1 \mathrm{H}\right)$, 5.56-5.53 (m, $1 \mathrm{H}), 5.03-5.00(\mathrm{~m}, 1 \mathrm{H}), 4.45(\mathrm{~s}, 2 \mathrm{H}), 4.05$ $\left(\mathrm{dd}, 3 \mathrm{~J}_{\mathrm{HH}}=5.05,7.0 \mathrm{~Hz}, 1 \mathrm{H}\right), 2.25-2.15(\mathrm{~m}, 2 \mathrm{H}), 2.10-1.90$ $(\mathrm{m}, 2 \mathrm{H}), 1.96$ (s, $3 \mathrm{H}) \mathrm{ppm} .{ }^{13} \mathrm{C}$ NMR (125 mHz, DMSO-d6) $\delta: 174.0,173.9,167.2,167,164.9,164.2,153.1,151.9,151.4$, 149.4, 141.4, 129.5, 126.7, 118.7, 112.8, 110.6, 53.9, 45.7, $30.1,27.9,18.7 \mathrm{ppm}$.

Superparamagnetic iron oxides (size 20-50 nm), were obtained from Sigma-Aldrich Chemical Co (St. Louis, MO). The surfaces of $0.1 \mathrm{~g}$ iron nanoparticles were modified in $2.5 \mathrm{~mL}$ toluene, adding $0.5 \mathrm{~mL}$ trimethoxysilyl propyl methacrylate. These silylated superparamagnetic iron oxide nanoparticles were mixed with a $5 \mathrm{mg} / \mathrm{mL}$ molality of $1 \mathrm{~mL}$ Ma-Fol in $1 \mathrm{~mL}$ dimethyl sulfoxide (Sigma-Aldrich Chemical Co). The chemicals were diluted in dimethyl sulfoxide before addition to the cultures. The final concentration of dimethyl sulfoxide was $0.1 \%$.

\section{Cell culture}

5RP7 (H-ras-transformed rat embryonic fibroblasts) and NIH/3T3 (a control cell line of normal mouse embryonic fibroblasts) were used in these experiments. Frozen stock vials of the cells were thawed and used. Cells were routinely cultured at $37^{\circ} \mathrm{C}$ in a humidified atmosphere with $5 \% \mathrm{CO}_{2}$ in $25 \mathrm{~cm}^{2}$ flasks containing $5 \mathrm{~mL}$ of Dulbecco's modified Eagle's medium, supplemented with $10 \%$ fetal 
bovine serum, $2 \mathrm{mM}$ L-glutamine, $50 \mathrm{IU} / \mathrm{mL}$ penicillin, and $50 \mathrm{mg} / \mathrm{mL}$ streptomycin. The medium was changed every third day. For subculture, the cells were washed twice with phosphate-buffered saline and incubated with trypsin-ethylenediamine tetra-acetic acid solution ( $0.25 \%$ trypsin, $1 \mathrm{mM}$ ethylenediamine tetra-acetic acid) for 2 minutes at $37^{\circ} \mathrm{C}$ to detach the cells, and the complete media were then added into the flask at room temperature to inhibit the effect of trypsin. The cells were washed twice by centrifugation and resuspended in the complete media for reseeding and growing in new culture flasks. Cell viability was determined through staining with trypan blue, and cells were counted using a hemocytometer.

To study the cellular uptake of the nanoparticles by flow cytometry and TEM, Ma-Fol-modified magnetic nanoparticles were added to the cell culture media at concentrations of $2.5 \mu \mathrm{g} / \mathrm{mL}, 4.5 \mu \mathrm{g} / \mathrm{mL}$, and $9 \mu \mathrm{g} / \mathrm{mL}$. The cells were cultured and then reseeded with the nanoparticle-dispersed culture media. After 24 and 48 hours of incubation at $37^{\circ} \mathrm{C}$, the cells were washed twice with phosphate-buffered saline, detached using trypsin-ethylenediamine tetra-acetic acid solution, and resuspended in culture media. In control cultures, the cells were placed in $5 \mathrm{~mL}$ of medium without magnetic nanoparticles at the same cell density.

\section{Flow cytometry}

Annexin V-fluorescein isothiocyanate (FITC) is a sensitive probe for identifying apoptotic cells. It binds to negatively charged phospholipid surfaces with a higher specificity for phosphatidylserine, a membrane phospholipid, than for most other phospholipids. ${ }^{21}$ In apoptotic cells, phosphatidylserine is translocated from the inner leaflet of the plasma membrane to the outer leaflet, thereby exposing phosphatidylserine to the external environment. ${ }^{22}$ A FACSAria (BD Corporation, Bedford, MA) flow cytometer was used for analysis of the cells. A recent report suggested that the uptake of $\mathrm{Fe}_{3} \mathrm{O}_{4}$ nanoparticles by cells could be quantitatively measured using flow cytometric light scatter. ${ }^{6}$ Annexin $\mathrm{V}$ binding was performed using an AnnexinV-FITC kit (BD Corporation) as described by the manufacturer. Cells were washed twice with cold phosphate-buffered saline and were then resuspended in $1 \times$ binding buffer at a concentration of $1 \times 10^{6}$ cells $/ \mathrm{mL}$, after which $100 \mu \mathrm{L}$ of solution $\left(1 \times 10^{5}\right.$ cells $)$ was transferred to a $5 \mathrm{~mL}$ culture tube. Annexin V-FITC $5 \mu \mathrm{L}$ and propidium iodide $5 \mu \mathrm{L}$ were added, and the cells were then incubated for 15 minutes at room temperature in the dark, after which $400 \mu \mathrm{L}$ of $1 \times$ binding buffer was added to each tube and analyzed in the FACSAria.

\section{Transmission electron microscopic analysis}

Uptake of nanoparticles modified with folic acid by NIH/3T3 and 5RP7 cancer cells, as well as nanoparticle size and morphology, were determined using a TEM (FEI Tecnai BioTWIN). Samples for TEM measurement were prepared by dispersing the particles in dimethyl sulfoxide. Cells were deposited on Formvar-coated 200-300 mesh copper grids and dried, fixed with $2.5 \%$ glutaraldehyde in $0.1 \mathrm{M}$ phosphate buffer ( $\mathrm{pH} 7.4$ ), and left in phosphate-buffered saline overnight at $4^{\circ} \mathrm{C}$. After being embedded in agar and after fixation in $2 \%$ osmium tetroxide, the cells were dehydrated in graded ethanol, ie, 70, 90, 96, and 100\%. The cells were then embedded in EPON 812 epoxy. They were thin-sectioned using a diamond knife to a maximum thickness of $100 \mathrm{~nm}$. The sections were stained with lead citrate and uranyl acetate.

\section{Results and discussion}

A logical method to promote internalization of nanoparticles is to modify their surface with a ligand such as folic acid which can be efficiently taken up by cells through receptormediated endocytosis. ${ }^{23}$ Folic acid binds to the folate receptors at cell surfaces with very high affinity and is internalized by receptor-mediated endocytosis. ${ }^{24,26}$ More importantly, folic acid is stable, poorly immunogenic, and has the ability to target cancer cells preferentially because the folate receptor is frequently overexpressed on the surface of cancer cells.

Flow cytometry is a process whereby physical or biochemical parameters of single biological cells or particles are measured as the cells move through a fluidic channel. ${ }^{27}$ The Annexin $\mathrm{V}$ binding assay provides a very specific, rapid, and reliable technique to detect apoptosis by flow cytometry or by fluorescence microscopy. ${ }^{28,29}$ FITC is a very useful fluorescent moiety that can be used to label essentially any protein. FITC-conjugated Annexin V is used to detect apoptotic cells in a diverse range of cell types and in response to many different proapoptotic stimuli. ${ }^{28,29}$

Iron nanoparticles were successfully modified with MaFol as described in the Methods section. The nanoparticles appeared to be spherical, and diameters were 24-30 nm. Ma-Fol was used to target preferentially cancer cells with folate receptors expressed on their surfaces, and to facilitate the nanoparticles to transit across the cell membrane. Annexin V-FITC allows detection of cell surface changes 
that occur early during apoptosis, because Annexin V binds to phosphatidylserine which becomes exposed on the outer surface of the plasma membranes by flipping from the inner side of the membrane..$^{22,30,31}$ Exposure of phosphatidylserine during apoptosis precedes nuclear changes. This change in membrane surface is important for macrophages to recognize cells undergoing apoptosis. ${ }^{30,32}$ Annexin V, an anticoagulant protein, binds to phosphatidylserine with high affinity. Thus, by staining cells with Annexin V-FITC and additionally with DNA-specific fluorochrome, eg, propidium iodide, it is possible to identify live cells, early apoptotic cells, as well as late apoptotic and necrotic cells, by flow cytometry. ${ }^{22,33}$ Subsequently, Annexin V-FITC binds to cells expressing phosphatidylserine, an early marker of apoptosis on the cell surface. Target cells are gated upon as propidium iodide-negative and quantified with respect to their Annexin $\mathrm{V}$ positivity. The shift from Annexin $\mathrm{V}^{\text {neg }}$ to Annexin $\mathrm{V}^{\text {high }}$ is a discrete event, such that all target cells fall within discernible populations with respect to Annexin V. Dead or dying cells are then stained with Annexin V-FITC. ${ }^{34}$ Annexin V has been used to detect apoptotic cells in a wide variety of cell types. Externalization of phosphatidylserine has been demonstrated in plasma membrane permeability changes, as measured by propidium iodide uptake and Annexin V binding, and precedes the morphological features of apoptosis as assessed by flow cytometric analysis of cell shrinkage. ${ }^{29,34}$ The sensitivity and early kinetics of Annexin $\mathrm{V}$ binding make it an ideal marker for cell death in a flow cytometric assay. ${ }^{34}$ Analysis of Annexin V/propidium iodidestained cells by flow cytometry allows quantitation of the fraction of cells that are Annexin V-negative and propidium iodide-negative (double negative), Annexin V-positive and propidium iodide-negative (single positive), or Annexin V-positive and propidium iodide-positive (double positive) ${ }^{28}$ A number of detectors are aimed at the point where the stream passes through the light beam, ie, one in line with the light beam (forward scatter) and several perpendicular to it (side scatter) and one or more fluorescent detectors. Forward scatter correlates with the cell volume, and side scatter depends on the inner complexity of the particle (ie, shape of the nucleus, amount and type of cytoplasmic granules, or membrane roughness). ${ }^{35}$ Data analysis was performed with Diva Software (BD FACS Diva software 6.0; BD Corporation, Bedford, MA). Analyses were conducted on 10,000 cells in each case. Apoptosis was quantitatively confirmed by analyzing the percentage of early apoptotic cells using Annexin V-FITC/propidium iodide double staining. A marker of early apoptosis, measured by Annexin-V, is phosphatidylserine, which is released as a result of redistribution of the plasma membrane of the cells. ${ }^{22}$ Three main populations of cells were distributed in dot-plots for viable cells Q3 (Annexin V-negative/propidium iodidenegative), early apoptotic cells Q4 (Annexin V-positive/ propidium iodide-negative), and late apoptotic and necrotic cells Q2 (Annexin V-positive/propidium iodide-positive). The cytotoxicity of folic acid-modified nanoparticles was determined by exposing normal cells and cancer cells to various concentrations in Dulbecco's Modified Eagle's Medium for 24 and 48 hours. Nanoparticles were dispersed in dimethyl sulfoxide. The final concentration of dimethyl sulfoxide was $0.1 \%$. The results and respective percentages of cells in apoptotic regions for both NIH/3T3 and 5RP7 cells are given in Figures 1 and 2. The results indicate that there was no significant loss of cell survival if the incubated concentration of Ma-Fol-modified nanoparticles was $4.5 \mu \mathrm{g} / \mathrm{mL}$ or below in cancer cells. As the concentration increased to $9 \mu \mathrm{g} / \mathrm{mL}$, the rate of viability was close to that of normal cells. These results confirm that the cells are saturated with Ma-Fol-modified nanoparticles at a concentration of $4.5 \mu \mathrm{g} /$ $\mathrm{mL}$. Up to this concentration, the magnetic nanoparticles were aggregated and had difficulty penetrating into the cancer cells. Figure 2 shows cell death due to the Ma-Folmodified magnetic nanoparticles at $4.5 \mu \mathrm{g} / \mathrm{mL}$ for 24 hours in cancer cells. When cells were exposed to a nanoparticle concentration of $4.5 \mu \mathrm{g} / \mathrm{mL}$ for 24 hours, cell survival decreased to $83 \%$. When incubation time was extended to 48 hours, cell viability decreased further to $80 \%$. As shown in Figure 2, folic acid-modified nanoparticles caused worse damage to cancer cells than to normal cells. The population of Annexin V-positive live cells increased in a time-dependent manner, and most (12.9\%) of the cells became Annexin V-positive at 48 hours (Figure 2). When cancer cells were incubated with modified magnetic Ma-Fol nanoparticles for 48 hours $(9 \mu \mathrm{g} / \mathrm{mL})$, the population of Annexin V-positive live cells was found to be $7.3 \%$ (Figures $2 \mathrm{~A}$ and 2B). Cells in the late stages of apoptosis are located in the bottom right quadrant of the dot-plot as double positive Annexin V-FITCand propidium iodide-binding cells because, at this stage, the cell membranes are damaged and propidium iodide has penetrated into the cell. In the later stages of apoptosis, propidium iodide enters the cell, leading to a double positive population. ${ }^{28}$ Cells undergoing necrotic cell death also stain as double positive for Annexin $\mathrm{V}$ and propidium iodide, as discussed earlier.

Flow cytometry by this double staining method enables clear detection of three populations of cells (viable, apoptotic, 
A

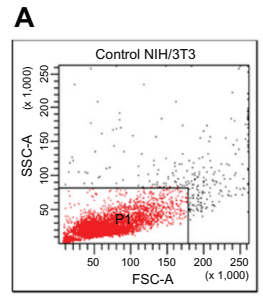

$\mathbf{F}$

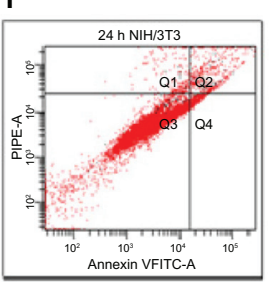

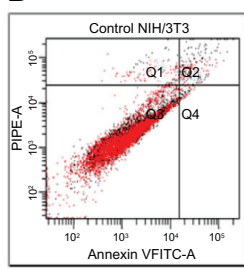

G

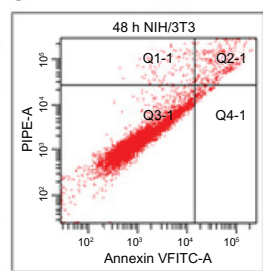

C

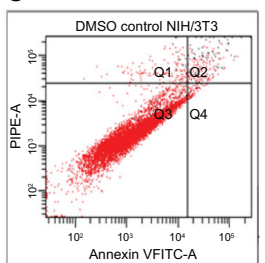

H

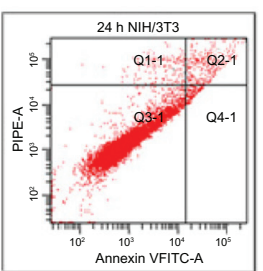

D
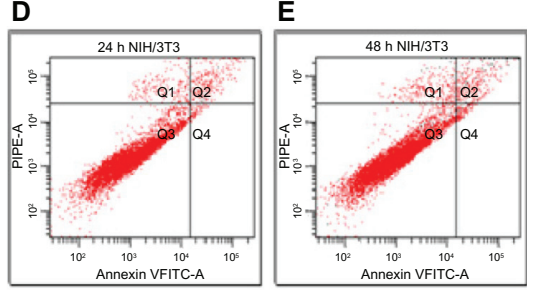

I

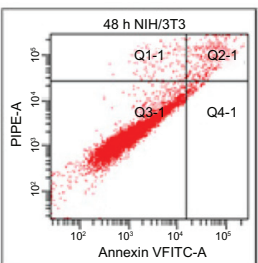

Figure I Flow cytometric analysis of $\mathrm{NIH} / 3 \mathrm{~T} 3$ cells by double labeling with Annexin V-fluorescein isothiocyanate and propidium iodide. Unfixed cells from control and treated groups were labeled with Annexin $V$-fluorescein isothiocyanate and propidium iodide and then fixed and analyzed on a flow cytometer. Dual parameter dot-plot of propidium iodide-phycoerytrin (x-axis), Annexin V-fluorescein isothiocyanate fluorescence (y-axis) showing logarithmic intensity. Quadrants are viable cells Q3 (Annexin V-negative/propidium iodide-negative), early apoptotic cells Q4 (Annexin V-positive/propidium iodide-negative), and late apoptotic and necrotic cells Q2 (Annexin V-positive/propidium iodide-positive). Percentage of apoptotic cells are A) control cells, I.5\%; B) dimethyl sulfoxide control cells, I.6\%; C) Ma-Fol-modified magnetic nanoparticles, $2.5 \mu \mathrm{g} / \mathrm{mL}, 24$ hours, 2.7\%; D) Ma-Fol-modified magnetic nanoparticles $2.5 \mu \mathrm{g} / \mathrm{mL}$, 48 hours, $2.8 \%$; F) Ma-Fol-modified magnetic nanoparticles $4.5 \mu \mathrm{g} / \mathrm{mL}, 24$ hours, $4.3 \%$; G) Ma-Fol-modified magnetite nanoparticles $4.5 \mu \mathrm{g} / \mathrm{mL}$, 48 hours, $4.7 \%$; H) Ma-Fol-modified magnetic nanoparticles $9 \mu \mathrm{g} / \mathrm{mL}, 24$ hours, $2.9 \%$; I) Ma-Fol-modified magnetic nanoparticles $9 \mu \mathrm{g} / \mathrm{mL}, 48$ hours, $3.1 \%$.

Abbreviation: Ma-Fol, methacrylamido-folic acid.

and necrotic). Thus, the early apoptotic cells bind only to Annexin-V FITC, and late apoptotic cells to both Annexin V-FITC and propidium iodide, and viable cells do not take up any of the dye. The Annexin V-FITC/propidium iodide population was considered to reflect normal healthy cells, whereas Annexin V-FITC-positive/propidium iodide-negative cells were taken to show early apoptosis. Annexin V-FITC -positive/propidium iodide-negative cells were in late apoptosis or necrosis. ${ }^{35}$

Our flow cytometric analysis has shown that 48 hours of treatment with Ma-Fol-modified magnetic nanoparticles caused apoptosis in a 5RP cell line in a
A

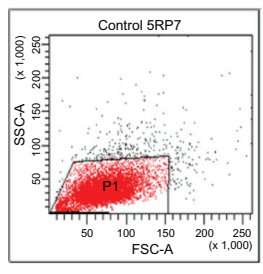

$\mathbf{F}$

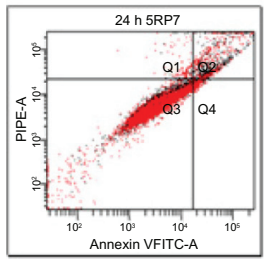

B

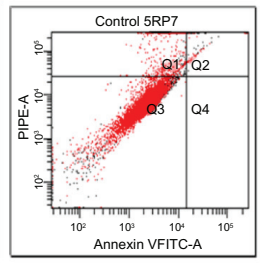

G

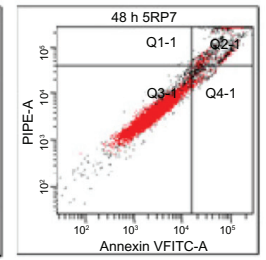

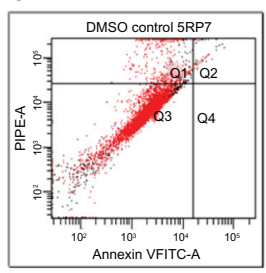

H

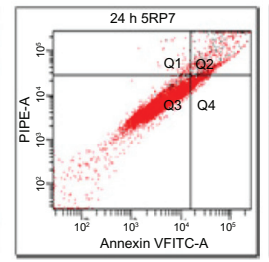

D

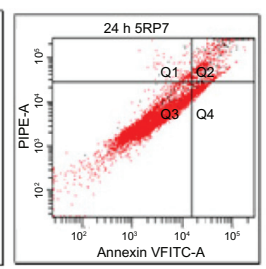

I

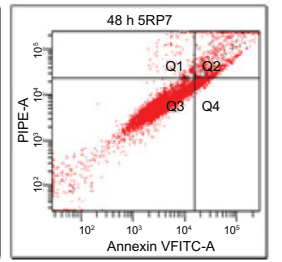

Figure 2 Flow cytometric analysis of 5 RP7 (H-ras-transformed fibroblasts) by double labeling with Annexin V-fluorescein isothiocyanate and propidium iodide. Control cells were labeled with Annexin V-fluorescein isothiocyanate and propidium iodide, and then fixed and analyzed on a flow cytometer. Quadrants are viable cells Q3 (Annexin V-negative/propidium iodide-negative), early apoptotic cells Q4 (Annexin V-positive/propidium iodide-negative) and late apoptotic and necrotic cells Q2 (Annexin V-positive/propidium iodide-positive). Percentage of apoptotic cells are A) control cells, I.1\%; B) dimethyl sulfoxide control cells, I.2\%; C) Ma-Fol-modified magnetic nanoparticles $2.5 \mu \mathrm{g} / \mathrm{mL}, 24$ hours $7.2 \%$; D) Ma-Fol modified magnetic nanoparticles $2.5 \mu \mathrm{g} / \mathrm{mL}$, 48 hours, $8.1 \%$; E) Ma-Fol-modified magnetic nanoparticles $4.5 \mu \mathrm{g} / \mathrm{mL}$, 24 hours, 10.5\%; F) Ma-Fol-modified magnetic nanoparticles $4.5 \mu \mathrm{g} / \mathrm{mL}$, 48 hours, $12.9 \%$.

Abbreviation: Ma-Fol, methacrylamido-folic acid. 
concentration-dependent manner. Ma-Fol-modified magnetic nanoparticles at a dose of $4.5 \mu \mathrm{g} / \mathrm{mL}$ showed $12.9 \%$ cells in the apoptotic zone in the case of NIH/3T3 cells, and the same concentration produced apoptosis in $4.7 \%$ of cells in dot-plot analysis. Late apoptosis and necrosis increased steadily following the increase at a concentration of $4.5 \mu \mathrm{g} / \mathrm{mL}$. Flow cytometric determination of cell cycle phase distribution has further confirmed that folic acidmodified magnetic nanoparticles cause cell cycle deformation in a cancer cell line.

The results of this study confirm that cancer cells have more folate receptors, and that a $4.5 \mu \mathrm{g} / \mathrm{mL}$ concentration of folic acid-modified magnetic nanoparticles causes apoptosis in 5RP7 cells. The uptake of folic acid-modified nanoparticles by cancer cells was also much higher than that of normal cells. This indicates that folic acid modification not only facilitates the nanoparticles to target specific cells, but also increases the yield of cell internalization. The interaction between folic acid and folate receptors expressed on the surface of cancer cells might have contributed to the improvement of nanoparticle uptake, based on receptormediated endocytosis. ${ }^{37}$

The schemes for the modification of nanoparticles display TEM images (Figure 3) of Ma-Fol-modified with $\mathrm{Fe}_{3} \mathrm{O}_{4}$ nanoparticles for this purpose, firstly, magnetic nanoparticles were imaged. These images indicate that all the $\mathrm{Fe}_{3} \mathrm{O}_{4}$ nanoparticles were in the nanosized range. The average particle size is about $30 \mathrm{~nm}$. Figure 4 shows the TEM images of NIH/3T3 cells not treated with Ma-Fol-modified magnetic nanoparticles. Figure 5 shows the uptake of folic acid-modified nanoparticles into normal cells at 24 hours and 48 hours. The incubation of cells with folic acid-modified nanoparticles does not differ. The viability of normal cells after each incubation time with the nanoparticles was close to that of control cells, and was in the $95 \%-96 \%$ range in flow cytometric analysis. The uptake of magnetic nanoparticles by cancerous
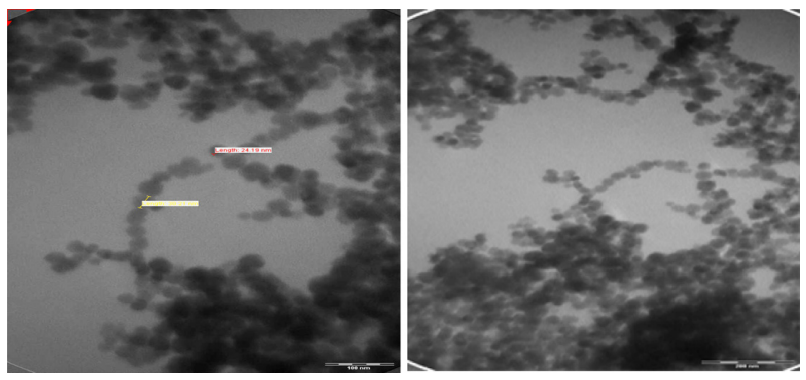

Figure 3 Transmission electron micrographs of $\mathrm{Fe}_{3} \mathrm{O}_{4}$ magnetic nanoparticles. A) $160,000 \times$; B) $105,000 \times$.
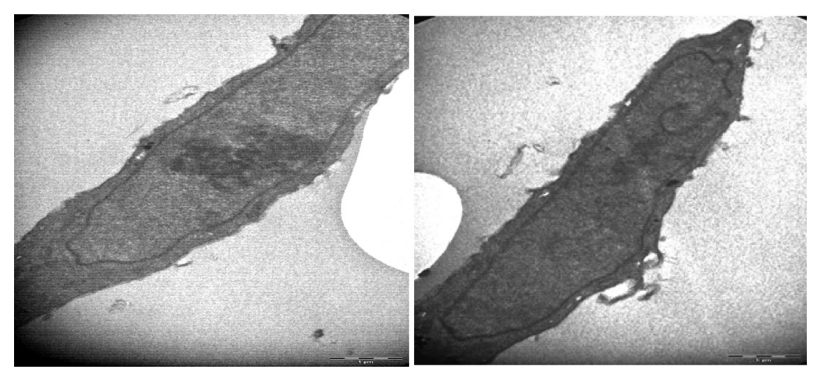

Figure 4 Transmission electron micrographs of NIH/3T3 cell $(16,500 \times)$ not treated with folic acid-modified magnetic nanoparticles.

rat 5RP7 fibroblasts is shown in Figure 7. After 48 hours of culture in media containing folic acid-modified nanoparticles, the morphology and viability of normal fibroblast cells containing the modified nanoparticles were close to that of the control cells, suggesting biocompatibility of the nanoparticles. The TEM and flow cytometry results showed that folic acid-modified nanoparticles were internalized into both normal cells and cancer cells. The immobilization of folic acid on the nanoparticles was demonstrated by increasing the amount of nanoparticle uptake into cancer cells in comparison with normal cells. This suggests that the modification of magnetic nanoparticles with Ma-Fol could be used to resist nonspecific uptake and thus avoid their recognition by macrophage cells, and simultaneously facilitate nanoparticle uptake to specific cancer cells for cancer therapy.

In flow cytometry results, the population of Annexin $\mathrm{V}$-positive live cells in the cancer cell line increased in a time-dependent manner, and most $(12.9 \%)$ of the cells became Annexin V-positive at 48 hours at a concentration of $4.5 \mu \mathrm{g} / \mathrm{mL}$. The results indicate that there was no significant loss of cell survival if the incubated concentration of Ma-Fol modified nanoparticles is $4.5 \mu \mathrm{g} / \mathrm{mL}$ or below in cancer cells. As the concentration increased to $9 \mu \mathrm{g} / \mathrm{mL}$, the

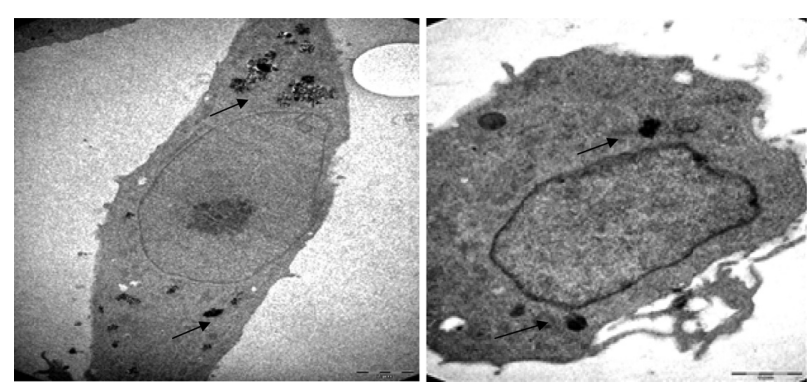

Figure 5 Transmission electron micrographs of a IH/3T3 cell. A) $(6000 \times)$ treated with $4.5 \mu \mathrm{g} / \mathrm{mL}$ Ma-Fol-modified magnetic nanoparticles for 24 hours. B) (I6,500× treated with $4.5 \mu \mathrm{g} / \mathrm{mL}$ folic acid-modified magnetic nanoparticles for 48 hours. Abbreviation: Ma-Fol, methacrylamido-folic acid. 


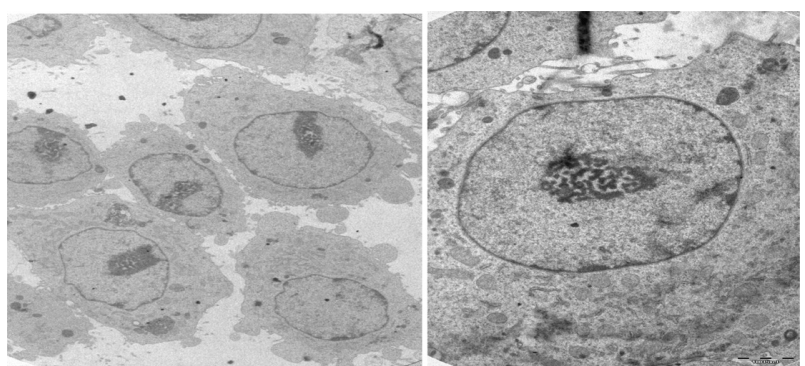

Figure 6 Transmission electron micrographs of 5RP7 cells not treated with folic acid-modified magnetic nanoparticles. C) 4200x; D) $8200 \times$.

rate of viability was close to that of normal cells. These results confirm that cells saturated with folic acid-modified nanoparticles are detected in the $4.5 \mu \mathrm{g} / \mathrm{mL}$ concentration. Up to this concentration, magnetic nanoparticles were aggregated and had difficulty penetrating the cells. In TEM analysis, the concentration of $4.5 \mu \mathrm{g} / \mathrm{mL}$ was used to compare the cancer cells and normal cells at 24 and 48 hours.

In normal cells, organelles and cell structures were not affected by the presence of Ma-Fol-modified nanoparticles inside the cells (Figure 5). However, cancer cells treated with the $4.5 \mu \mathrm{g} / \mathrm{mL}$ concentration of Ma-Fol-modified nanoparticles underwent apoptosis. A representative picture of intracellular nanoconjugate uptake by NIH/3T3 cells during a 24-hour and 48-hour treatment is shown in Figures 5 and 6. The amount of intracellular uptake of the nanoparticles can be seen in normal cells, whereas in the 5RP7 cell line the amount of the nanoconjugate was increased and cell modifications were damaged, Figure 7 clearly illustrates the internalization of Ma-Fol-modified nanoparticles and their localization near the nucleus and a great number of apoptotic particles. This picture shows clearly that nanoconjugate uptake was maximum, with 5RP7 cells having maximum receptor expression, and hence the most intense color of the pellet, whereas the uptake gradually decreased with reduction in folate receptor expression
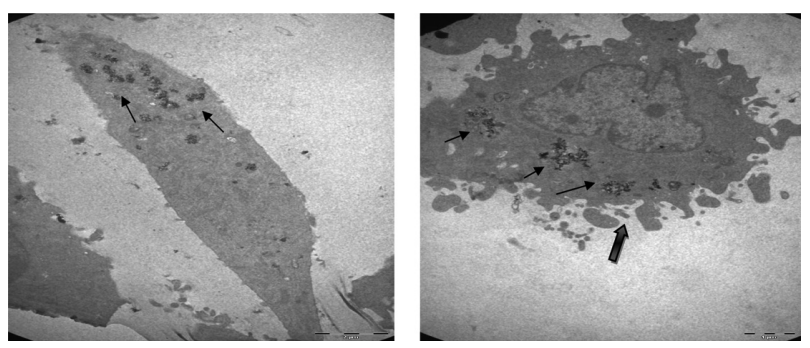

Figure 7 Transmission electron micrographs of 5RP7 cells; E) (8200x) (treated with $4.5 \mu \mathrm{g} / \mathrm{mL}$ folic acid-modified magnetic nanoparticles for 24 hours. F) (I I,500x) treated with $4.5 \mu \mathrm{g} / \mathrm{mL}$ folic acid-modified magnetic nanoparticles for 48 hours leading to apoptotic blebbing. and, accordingly, the intensity of the color of the pellet in the case of NIH/3T3. The picture confirms our hypothesis about the targeting efficacy of nanoconjugates containing folic acid, ie, that a positive correlation exists between maximum folate receptor expression and maximum uptake of nanoconjugates. The 5RP7 cells with $90 \%$ receptor expression showed maximum uptake, and the NIH/3T3 cells showed the least. This is further substantiated by TEM and flow cytometry analysis, confirming that folic acid-modified magnetic nanoparticles can be used as a targeting agent.

Ma-Fol-modified magnetic nanoparticles represent a potential novel delivery system for compounds with anticancer activity because the folate receptor is frequently overexpressed in cancer cells. Moreover, it may increase our ability to target drugs to tumor cells, protect the drug from in vivo degradation, and reduce drug toxicity. Further studies are in progress to test this new drug delivery system in vivo.

\section{Conclusion}

This study describes a simple method of attaching Ma-Fol to $\mathrm{Fe}_{3} \mathrm{O}_{4}$ nanoparticles. This modification containing folic acid can be used for successful targeting of tumor cells expressing the folate receptor. Future studies will focus on determining the stability and targeting efficacy of this modification in vivo. This study has important implications in cancer cell imaging, tumor ablation, and drug delivery because of its targeting efficacy. Furthermore, it needs to be investigated whether nanoparticles could cause long-term changes in systemic activity. However, the effect and usage of such combinations need to be investigated further in in vivo experiments.

\section{Acknowledgment}

This work was supported by the Technical and Research Council of Turkey (Grant No, 108T286), and the Culture and TEM facilities at Anadolu University Plant, Drug, and Scientific Research Center.

\section{Disclosure}

The authors report no conflicts of interest in this work.

\section{References}

1. Hu S, Zhang Y. Endostar-loaded PEG-PLGA nanoparticles: in vitro and in vivo evaluation. Int J Nanomedicine. 2010;5:1039-1048.

2. Ansary A, Faddah LM. Nanoparticles as biochemical sensors. Nanotechnol Sci Appl. 2010;3:65-76.

3. Shenoy D, Fu W, Li J, et al. Surface functionalization of gold nanoparticles using hetero-bifunctional poly(ethylene glycol) spacer for intracellular tracking and delivery. Int J Nanomedicine. 2006;1:51-57. 
4. Sonvico F, Mornet S, Vasseur S, et al. Folate-conjugated 1ron oxide nanoparticles for solid tumor targetting as potential specific magnetic hyperthemia mediators: synthesis, physicochemical characterization, and in vitro experiments. Bioconjug Chem. 2005;16:1181-1188.

5. Wu W, Chen B, Cheng J, et al. Biocompability of $\mathrm{Fe}_{3} \mathrm{O}_{4} / \mathrm{DNR}$ magnetic nanoparticles in the treatment of hematologic malignancies. Int J Nanomedicine. 2010;5:1079-1084.

6. Jing $\mathrm{H}$, Wang J, Yang $\mathrm{P}$, et al. Magnetic $\mathrm{Fe}_{3} \mathrm{O}_{4}$ nanoparticles and chemotherapy agents interact synergistically to induce apoptosis in lymphoma cells. Int J Nanomedicine. 2010;5:999-1004.

7. Wang J, Chen Y, Chen B, et al. Pharmacokinetic parameters and tissue distribution of magnetic $\mathrm{Fe}_{3} \mathrm{O}_{4}$ nanoparticles in mice. Int J Nanomedicine. 2010;5:861-866.

8. Lai TY, Lee CW. Killing of cancer cell line by photoexcitation of folic acid-modified titanium dioxide nanoparticles. J Photochem Photobio A Chem. 2009;204:148-153.

9. Weissleder R, Cheng HC, Bogdanova A. Magnetically labeled cells can be detected by MR imaging. J Magn Reson Imaging. 1997;7: 258-263.

10. Lowry MB, Duchemin AM, Robinson JM, Anderson CL. Functional separation of pseudopod extension and particle internalization during Fc gamma receptor-mediated phagocytosis. J Exp Med. 1998;187: 161-176.

11. Stella B, Arpicco S, Peracchia MT, et al. Design of folic acid-conjugated nanoparticles for drug targeting. J Pharm Sci. 2000;89: 1452-1464.

12. Quintana A, Raczka E, Piehler L, et al. Design and function of a dendrimer-based therapeutic nanodevice targeted to tumor cells through the folate receptor. Pharm Res. 2002;19:1310-1316.

13. Bhattacharya R, Patra CR, Earl A, et al. Attaching folic acid on gold nanoparticles using noncovalent interaction via different polyethylene glycol backbones and targeting of cancer cells. Nanomedicine. 2007; 3:224-238.

14. Andrew RH, Philip SL. Folate receptor-mediated drug targetting: From therapeutics to diagnostics. J Pharm Sci. 2005;94:2135-2146.

15. Holm J, Hansen SI, Hoier-Madsen M, Bostad L. High-affinity folate binding in human choroid plexus. Characterization of radioligand binding, immunoreactivity, molecular heterogeneity and hydrophobic domain of the binding protein. J Biochem. 1991;280:267-271.

16. Yeh TC, Zhang W, Ildstad, ST, Ho C. Intracellular labeling of T-cells with superparamagnetic contrast agents. Magn Reson Med. 1993;30: 617-625.

17. Schoepf U, Marecos E, Melder R, et al. Intracellular magnetic labeling of lymphocytes for in vivo trafficking studies. Biotechniques. 1998;24: 642-651.

18. Moore A, Basilion JP, Chiocca EA, Weissleder R. Measuring transferrin receptor gene expression by NMR imaging. Biochim Biophys Acta. 1998;1402:239-249.

19. Hür D, Ekt SF, Say R. N-acylbenzotriazole mediated synthesis of some methacrylamido amino acids. Lett. Org. Chem. 2007;4:585-587.

20. Katritzky AR, Zhang Y, Singh SK. Synthesis. J. Synth. Org. Chem. 2003;18:2795-2798.
21. Cao C, Subhawong T, Albert JM, et al. Inhibition of mammalian target of rapamycin or apoptotic pathway induces autophagy and radiosensitizes PTEN null prostate cancer cells. Cancer Res. 2006;66: 10040-10047.

22. Vermes I, Haanen C, Steffens-Nakken H, Reutelingsperger C. A novel assay for apoptosis: Flow cytometric detection of phosphatidylserine expression on early apoptotic cells using fluorescein labelled Annexin V. J Immunol Methods. 1995:184:39-51.

23. Zhang J, Rana S, Srivastava RS, Misra RDK. On the chemical synthesis and drug delivery response of folate receptor-activated, polyethylene glycolfunctionalized magnetite nanoparticles. Acta Biomater. 2008;4:40-48.

24. Kamen BA, Caston JD. Properties of a folate binding protein (FBP) isolated from porcine kidney. Biochem Pharmacol. 1986;35:2323-2329.

25. Lee RJ, Huang L. Folate-targeted, anionic liposome-entrapped polylysine-condensed DNA for tumor cell-specific gene transfer. J Biol Chem. 1996;271:8481-8487.

26. Lee RJ, Low PS. Folate-mediated tumor cell targeting of liposomeentrapped doxorubicin in vitro. Biochim Biophys Acta. 1995;1233:134-144.

27. Shapiro HM. Practical Flow Cytometry. 4th ed. Hoboken, NJ: Wiley and Sons; 2003.

28. Brumatti G, Sheridan C, Martin SJ. Expression and purification of recombinant annexin $\mathrm{V}$ for the detection of membrane alterations on apoptotic cells. Methods. 2008;44:235-240.

29. Martin SJ, Reutelingsperger CP, McGahon AJ, et al. Early redistribution of plasma membrane phosphatidylserine is a general feature of apoptosis regardless of the initiating stimulus: Inhibition by overexpression of Bcl-2 and Abl. J Exp Med. 1995;182:1545-1556.

30. Nakata M, Oyama Y, Okada Y, et al. Flow cytometric analysis on tri-n-butyltin-induced increase in annexin $\mathrm{V}$ binding to membranes of rat thymocytes. Environ Toxicol Pharmacol. 1999;7:267-273.

31. Pellicciari C, Bottone MG, Biggioera M. Detection of apoptotic cells by annexin V labeling at electron microscopy. Eur J Histochem. 1997;41:211-216.

32. Stuart M, Damoiseaux JG, Frederik PM, et al. Surface exposure of phosphatidylserine during apoptosis of rat thymocytes precedes nuclear changes. Eur J Cell Biol. 1998;76:77-83.

33. Mazur L, Augustynek A, Bochenek M. Flow cytometric estimation of the plasma membrane diversity of bone marrow cells in mice treated with WR-2721 and cyclophosphamide. Toxicology. 2002;171:63-72.

34. Goldberg JE, Sherwood SW, Clayberger C. A novel method for measuring CTL and NK cell-mediated cytotoxicity using annexin V and twocolor flow cytometry. J Immunol Methods. 1999;224:1-9.

35. Molecular Station. Available at: http://www.molecularstation.com/cell/ flow-cytometry. Accessed on January 22, 2010.

36. Conde de la Rosa L, Schoemaker MH, Vrenken TE, et al. Superoxide anions and hydrogen peroxide induce hepatocyte death by different mechanisms: Involvement of JNK and ERK MAP kinases. J Hepatol. 2006;44:918-929.

37. Antony AC. The biological chemistry of folate receptors. Blood. 1992; 79:2807-2820.
International Journal of Nanomedicine

\section{Publish your work in this journal}

The International Journal of Nanomedicine is an international, peerreviewed journal focusing on the application of nanotechnology in diagnostics, therapeutics, and drug delivery systems throughout the biomedical field. This journal is indexed on PubMed Central, MedLine, CAS, SciSearch ${ }^{\circledR}$, Current Contents ${ } /$ Clinical Medicine, Journal

\section{Dovepress}

Citation Reports/Science Edition, EMBase, Scopus and the Elsevier Bibliographic databases. The manuscript management system is completely online and includes a very quick and fair peer-review system, which is all easy to use. Visit http://www.dovepress.com/ testimonials.php to read real quotes from published authors. 